\title{
PRE-BOMB MARINE RESERVOIR AGES IN THE WESTERN PACIFIC
}

\author{
Kunio Yoshida ${ }^{1,2} \bullet$ Tatsuaki Hara $^{1} \bullet$ Dai Kunikita $^{1} \bullet$ Yumiko Miyazaki $^{1} \bullet$ Takenori Sasaki $^{1} \bullet$ \\ Minoru Yoneda ${ }^{3} \cdot$ Hiroyuki Matsuzaki $^{4}$
}

ABSTRACT. In this study, molluscan shells housed at the University Museum, the University of Tokyo, provided a new set of region-specific correction values $(\Delta \mathrm{R})$ for the western Pacific, in particular for the central part of the main islands in the Japanese Archipelago and the southwest islands of Japan. The values of 40 total samples were calculated from 11 regions. North of the main islands and in the Ryukyu Islands, the mean $\Delta \mathrm{R}$ values showed comparatively small values, $5-40{ }^{14} \mathrm{C}$ yr; in the central part of the main islands, these values were $60-90{ }^{14} \mathrm{C} \mathrm{yr}$.

\section{INTRODUCTION}

There are many shellmound remains in the Japanese Islands, and although an exact number is not known, it has been estimated at 2000-3000 (Sanseido Publishing Company 2002), with more than half from shell middens of the Jomon period. For a hunter-gatherer living near the sea, marine products and resources held an important role. Shell middens from the Incipient stage of the Jomon period were not found; instead, shell middens appeared in the first half of the Earliest stage, more than 10,000 yr ago. Radiocarbon dating of the samples excavated from the Natsushima shellmound in Kanagawa Prefecture was carried out $50 \mathrm{yr}$ ago. It gave a surprisingly old date of $>9000$ BP ( $9450 \pm 400$ BP for oyster shell and $9240 \pm 500$ BP for charcoal; Crane and Griffin 1960). Shellmounds of this time were small middens. The surface of the sea rose along with global warming (during the Jomon transgression), with sea levels rising the most in the Early stage of the Jomon period, before about 7000-6000 yr ago, some 2 3 m higher than the present mean sea level. Sea levels then decreased, and huge circular and horseshoe-shaped middens were formed in the Middle and Late stages of the Jomon.

The Kasori shellmound in Chiba Prefecture is one of the biggest shell middens in Japan, and 2 circular middens $(160 \times 140 \mathrm{~m})$ are connected. Charcoal samples dated to $4790 \pm 80 \mathrm{BP}$ for the lower layer and $3630 \pm 90 \mathrm{BP}$ for the upper layer (Kigoshi 1967). Because it is thought that occupation and residence habits were altered due to environmental changes, a detailed chronological investigation is necessary. To study the Kasori shellmound site, a large-scale investigating committee was organized, and charcoal samples were obtained in order to determine the age of remains and archaeological features. In addition to pottery and stone implements and other artifacts, shell and bone samples were collected and dated at the same time. In general, sample ages were estimated based on the chronological order and typology of the earthenware vessels collected. However, pillar materials, charcoal, and carbonized materials were not collected, and it is rare that they were saved even if collected. Therefore, from the middens excavated in the past, only shells have been preserved, so it is necessary to date shell samples to determine the age of the midden. Fortunately, when charred material adheres to a potsherd, it can be used for dating.

It is necessary to calibrate a conventional ${ }^{14} \mathrm{C}$ age of shell samples by using the marine calibration curve Marine04 (Hughen et al. 2004). The average of apparent ${ }^{14} \mathrm{C}$ ages in the world oceans was shown to be $405{ }^{14} \mathrm{C}$ yr older than the terrestrial products. This value comes from the model ocean

${ }^{1}$ The University Museum, the University of Tokyo, Tokyo, Japan.

${ }^{2}$ Corresponding author. Email: gara@um.u-tokyo.ac.jp.

${ }^{3}$ Graduate School of Frontier Science, the University of Tokyo, Kashiwa, Chiba, Japan.

${ }^{4}$ School of Engineering, the University of Tokyo, Tokyo, Japan.

C 2010 by the Arizona Board of Regents on behalf of the University of Arizona Proceedings of the 20th International Radiocarbon Conference, edited by A J T Jull RADIOCARBON, Vol 52, Nr 2-3, 2010, p 1197-1206 


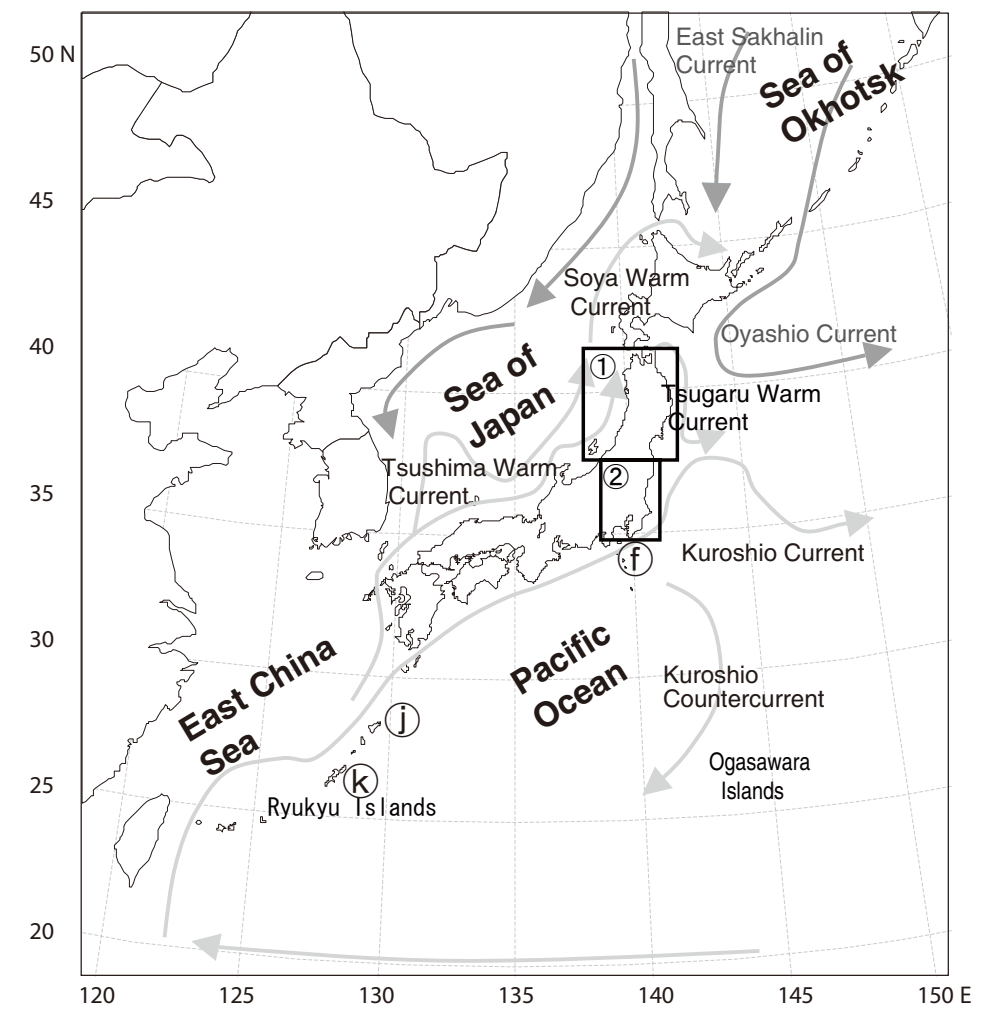

Figure 1 Location of sample collection and oceanographic conditions in the western Pacific. Letters in circles indicate the region where shells were collected. Arrows show currents: dark lines $=$ cold currents; light lines $=$ warm currents

reservoir age calculated by an ocean-atmosphere box diffusion model. However, depending on the location, marine reservoir ages can show various regional fluctuations, which are affected by upwelling of ${ }^{14} \mathrm{C}$-depleted deep-sea water or the inflow of river water, etc. The difference between the regional reservoir age and the mixed-layer reservoir age is the region-specific collection value, $\Delta \mathrm{R}$. This value may change depending on the place and time. If the value is not understood, the age of the shell sample therefore cannot be determined precisely.

Recently, marine reservoir ages around the Japanese Archipelago were reported, especially around the northern and southern islands. The surface layer of the North Pacific is affected by upwelling water aged $2000 \mathrm{BP}$ or less (Broecker 2002). In the western part of the region, the mean $\Delta \mathrm{R}$ for Sakhalin and Hokkaido was estimated as $393 \pm 32{ }^{14} \mathrm{C}$ yr (Kuzmin et al. 2001; Yoneda et al. 2007). Faunal remains of terrestrial and marine mammals excavated from 5 shell middens in Hokkaido Island, with ages ranging from the Jomon period (4900 BP) to the Ainu cultural period (800 BP), were dated and compared to the apparent ages. The difference in the ${ }^{14} \mathrm{C}$ age of northern fur seal and Japanese deer is $\sim 800{ }^{14} \mathrm{C}$ yr with estimated $\Delta \mathrm{R}$ values of $\sim 380{ }^{14} \mathrm{C}$ yr (Yoneda et al. 2001). The $\Delta \mathrm{R}$ values agreed well with pre-bomb shell results showing that the thermohaline circulation system does not show a big change after the hypsithermal interval.

On the other hand, in the Ryukyu Islands, the $\Delta \mathrm{R}$ values are smaller. Typical $\Delta \mathrm{R}$ values for water belonging to the Kuroshio Current in the south (northern Taiwan and Ishigaki Island) have a mean $\Delta \mathrm{R}$ value of $73 \pm 17{ }^{14} \mathrm{C}$ yr $(n=14)$ (Hideshima et al. 2001; Yoneda et al. 2007). For the Okinawa 
and Amami regions, the mean $\Delta \mathrm{R}$ value of $29 \pm 18{ }^{14} \mathrm{C}$ yr $(n=5)$ is slightly smaller (Yoneda et al. 2007).

There are few data for the central part of the main islands in the Japanese Archipelago. The $\Delta \mathrm{R}$ values at Miura Peninsula (region h in Figure 3) were estimated at $82 \pm 33$ and $77 \pm 32{ }^{14} \mathrm{C} \mathrm{yr}$ from marine shells uplifted by earthquakes (Shishikura et al. 2007). In addition, 3 values are reported: 109 ${ }^{14} \mathrm{C}$ yr for Shimoda (region i in Figure 3), $393{ }^{14} \mathrm{C}$ yr for Kashima-nada (near region c in Figure 2), and $-7^{14} \mathrm{C}$ yr for the Kii Peninsula (Yoneda et al. 2000). The local reservoir collections are estimated by paired shell and charcoal samples excavated in shellmounds in Aichi Prefecture, $-11 \pm 23$ ${ }^{14} \mathrm{C}$ yr $(n=4)$ for the Yoshigo shellmound $(2910 \sim 2800 \mathrm{BP})$ and $206 \pm 30{ }^{14} \mathrm{C} \mathrm{yr}(n=2)$ for the Kusubasama shellmound (6810 6730 BP) (Nakamura et al. 2007).

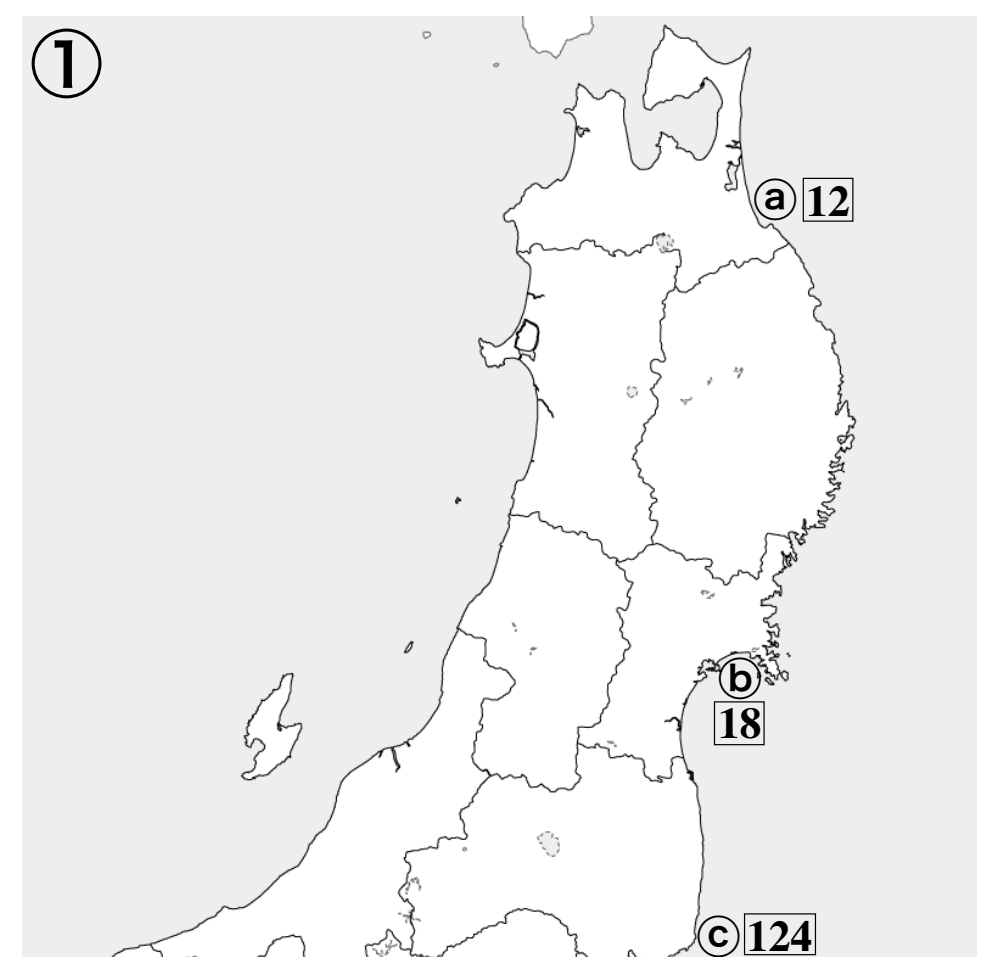

Figure 2. Location of sample collection in the Tohoku region and the mean $\Delta \mathrm{R}$ values

The Kuroshio Current flows east of the Japanese Islands from the south, and the Oyashio Current of the cold current flows from the north. With warming, the subtropical Kuroshio front advanced northward and reached Kashima in central Japan $\left(36^{\circ} \mathrm{N}\right)$ about $7000 \mathrm{yr}$ ago, and around $5500 \mathrm{yr}$ ago it retreated to the south (Chinzei et al. 1987). Also, from analysis of a piston core collected in the northwestern part of the Pacific Ocean in central Japan, it is presumed there was a big change in the marine environment not seen after the Early stage of the Jomon period (Niimura et al. 2006).

In this study, the apparent ${ }^{14} \mathrm{C}$ ages of shell samples collected from the 1880 s to 1920 s are measured to obtain the local reservoir collection values. There were 40 samples collected from 11 areas. Among those, 19 samples were collected in the Kanto District. Since many shellmounds exist in the Kanto area, the data of this area are important. 


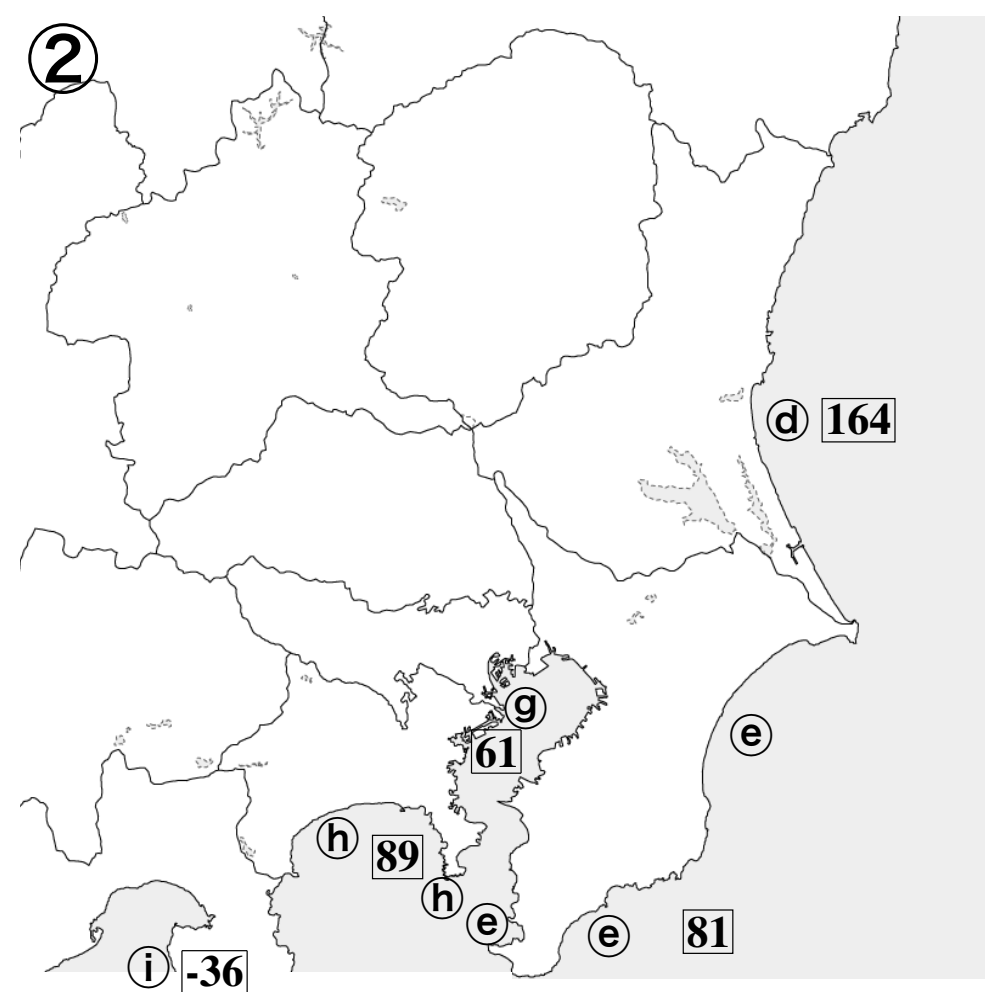

Figure 3 Location of sample collection in the Kanto region and the mean $\Delta \mathrm{R}$ values

\section{MATERIALS AND METHODS}

As in Yoneda et al. (2007), the shell materials used in this study have been stored at the Department of Paleontology of the University Museum, the University of Tokyo. The 2 sets of materials are grouped together in the same collection. The specimens were collected before World War II and have labels recording the collected localities and year as well as the collector's name. In this research, ${ }^{14} \mathrm{C}$ dating was performed on the samples collected on the main islands of Japan, especially the Kanto region (Figure 3) as well as the Izu Islands and the Ryukyu Islands. Most of the samples had evidence of live collection. Articulated bivalves and shells with organic tissues of ligament and other regions on their surface were selected.

The surface of the outer growing edge of the shell was manually cleaned, and a small piece of about $100 \mathrm{mg}$ was cut with a metal drill. The sample was then leached by $1 \mathrm{M} \mathrm{HCl}$ to remove secondarily recrystallized carbonate until $\sim 30 \%$ of the weight decreased. Each sample was reacted with $85 \%$ phosphoric acid within an evacuated glass vessel, and the carbon dioxide produced was purified cryogenically. Graphite samples of $1 \mathrm{mg}$ were reduced by hydrogen gas under iron powder catalyst at $650{ }^{\circ} \mathrm{C}$ (Yoshida et al. 2004). The ${ }^{14} \mathrm{C} /{ }^{12} \mathrm{C}$ ratio was measured by accelerator mass spectrometry (AMS) at the MALT facility, School of Engineering, the University of Tokyo (Yoshida and Miyazaki 2001).

The stable isotopic ratios of carbon and oxygen $\left(\delta^{13} \mathrm{C}\right.$ and $\left.\delta^{18} \mathrm{O}\right)$ were measured using a Finnigan MAT 252 isotopic ratio mass spectrometer attached to an automated carbonate device at the Department of Earth and Planetary Science, the University of Tokyo. 
${ }^{14} \mathrm{C}$ reservoir ages were calculated as the difference between the conventional ${ }^{14} \mathrm{C}$ age (apparent shell ${ }^{14} \mathrm{C}$ age) and the ${ }^{14} \mathrm{C}$ age of atmospheric $\mathrm{CO}_{2}$ at the year of collection (Stuiver and Braziunas 1993). The model ${ }^{14} \mathrm{C}$ ages in the atmosphere are based on the IntCal04 data set (Reimer et al. 2004). The regional correction value, $\Delta \mathrm{R}$, was estimated by the same procedure between the apparent shell ${ }^{14} \mathrm{C}$ age and surface ocean ${ }^{14} \mathrm{C}$ age at the year of collection using the marine model ${ }^{14} \mathrm{C}$ ages in the Marine04 data set (Hughen et al. 2004). Uncertainties for regional $\Delta R$ values are estimated by the standard error of the mean (see Table 1).

\section{RESULTS AND DISCUSSION}

Table 1 lists the results on sample isotopic values and ages. Stable isotopic data show reasonable values for marine carbonate, suggesting samples did not grow in estuarine conditions. The regions, from the Tohoku District through the Kanto region to the southwest, are affected by the Kuroshio Current and/or the Oyashio Current (and/or the Tsugaru Warm Current).

\section{Northeast Region of the Main Islands}

The $\Delta \mathrm{R}$ value is large, $393 \pm 32{ }^{14} \mathrm{C} \mathrm{yr}$, at the northeast shore in Hokkaido Island, as previously mentioned. On the other hand, in Hakodate, southwestern Hokkaido Island, the value of $\Delta \mathrm{R}$ was much smaller $\left(34 \pm 42{ }^{14} \mathrm{C}\right.$ yr) due to the influence of the Tsugaru Warm Current originating from the Tsushima Warm Current in the Sea of Japan (Yoneda et al. 2007). Two samples from Hachinohe (a in Figure 2) in Aomori Prefecture, northern end of the main islands, show similar reservoir ages $\left(12 \pm 24{ }^{14} \mathrm{C}\right.$ yr) to previous values for Hakodate, located on the opposite shore across the Tsugaru Strait on Hokkaido Island. Furthermore, the value is $18 \pm 35{ }^{14} \mathrm{C}$ yr in Shiogama (b in Figure 2) located $\sim 300 \mathrm{~km}$ south. A similar $\Delta \mathrm{R}$ value of $44 \pm 24{ }^{14} \mathrm{C} \mathrm{yr}(n=2$; Kuzmin et al. 2001) for the North Korean Current strongly suggests the Tsushima Warm Current has higher ${ }^{14} \mathrm{C}$ content, and it is estimated that the area containing " $a$ " and " $b$ " in Figure 2 is affected by these water masses.

In contrast, much higher $\Delta \mathrm{R}$ values of $124 \pm 36{ }^{14} \mathrm{C}$ yr for Soma, Fukushima Prefecture (c in Figure 2), and $164 \pm 35{ }^{14} \mathrm{C}$ yr for Oharai, Ibaraki Prefecture (d in Figure 3), were obtained. The location of the latter is near Kashima-nada, where a large $\Delta \mathrm{R}$ value of $393{ }^{14} \mathrm{C} \mathrm{yr}$ is reported (Yoneda et al. 2000). It appears that the area is under the influence of the Kuroshio Warm Current, but the reason for these high values is unclear. Since there are only a few data for this area, it will be necessary to increase the number of samples and to further examine the issue in the future.

\section{Kanto and Chubu Regions}

Mean values for the central Kanto District range from 60 to $90{ }^{14} \mathrm{C}$ yr (Figure 3). Samples of region e (Figure 3; Boso Peninsula, Chiba) show a big distribution of $\Delta \mathrm{R}$ values from $-38 \pm 36$ to $219 \pm 46$ ${ }^{14} \mathrm{C}$ yr $(n=7)$. Two samples were collected on the open sea coast (in Kujukuri and Kominato) and 5 samples in the Bay of Tokyo (Uraga Channel). Four of these samples collected in Heigun, Chiba (Table 1), show the same distribution though collected in the same place on the same day. The average of the $\Delta \mathrm{R}$ values is $38 \pm 20{ }^{14} \mathrm{C} \mathrm{yr}(n=4)$, and the standard deviation is $86{ }^{14} \mathrm{C}$ yr. The mean $\Delta \mathrm{R}$ value of the Boso Peninsula (region e in Figure 3) is $81 \pm 15{ }^{14} \mathrm{C}$ yr $(n=7)$. Furthermore, in the inner part of Tokyo Bay (region $\mathrm{g}$ in Figure 3), the mean $\Delta \mathrm{R}$ value is $61 \pm 22{ }^{14} \mathrm{C} \mathrm{yr}(n=3)$. There is a substantial input of terrestrial runoff to this area, which might cause contributions from both the hardwater effect or the effect of precipitation. Since the flux of a river is $1 / 7$ or less of the capacity of 62,100 million tons of Tokyo Bay (River Bureau 2004), judging from recent averages, it is presumed that the influence is small. Another problem is that the $\Delta \mathrm{R}$ values estimated by archaeological samples in the coast of Tokyo Bay changed depending on the type of shellfish (Yoshida et al. 2008). For 
$K$ Yoshida et al.

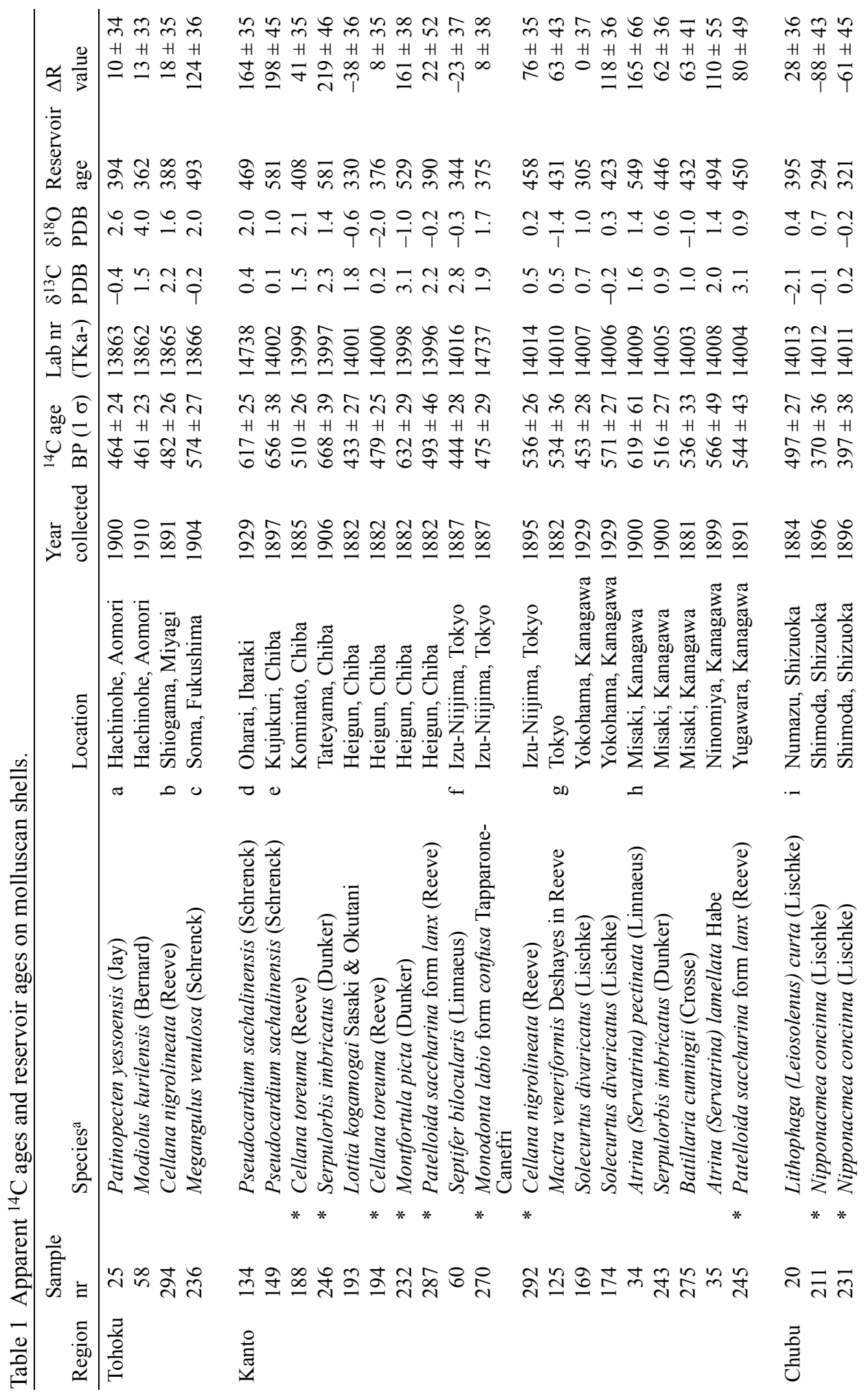




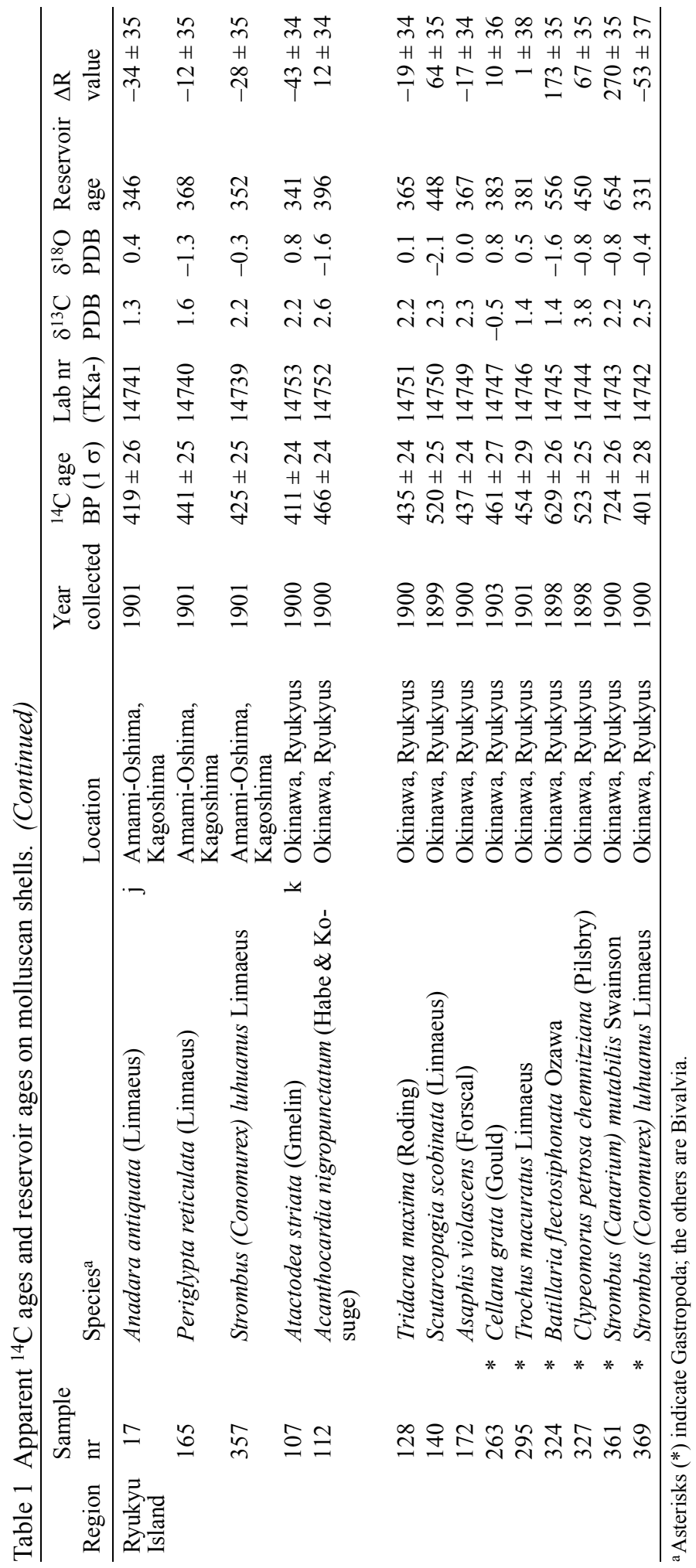


clams from $5500 \sim 3200 \mathrm{BP}$, the mean $\Delta \mathrm{R}$ value is $-65 \pm 20{ }^{14} \mathrm{C} \mathrm{yr}(n=3)$, and another species from the same family (Cyclina orlentalis Sowerby) from 7350 3200 BP shows $121 \pm 33{ }^{14} \mathrm{C}$ yr $(n=2)$. Furthermore, 2 samples collected at Yokohama (samples 169 and 174 in Table 1) in region g, which are the same species (plankton feeder) and collected at the same time, show values of $0 \pm 37$ and $118 \pm 36{ }^{14} \mathrm{C}$ yr, respectively.

In region $\mathrm{h}$ (Figure 3), the average $\Delta \mathrm{R}$ value is estimated as $89 \pm 22{ }^{14} \mathrm{C}$ yr $(n=5)$, which is extremely close to the previously reported values of $77 \pm 32{ }^{14} \mathrm{C}$ yr $(n=4)$ for $\mathrm{AD} 1703$ and $82 \pm 33$ ${ }^{14} \mathrm{C}$ yr $(n=5)$ for AD 1923 in the Miura Peninsula (Shishikura et al. 2007). Misaki (see Table 1) is located near the same site where Shishikura extracted the samples. Sagami Bay, which faces Misaki, suddenly becomes deep, with water depths exceeding $1500 \mathrm{~m}$ in the central part of the bay, but Tokyo Bay is not as deep. Since the mean values of $\Delta R$ of this region (e, g, and $h$ ) appear similar, it is estimated that the influence by upwelling old water is minor. In the meantime, for the Izu Peninsula and Suruga Bay (region $\mathrm{h}$ in Figure 3), the mean value of $\Delta \mathrm{R}$ is $-36 \pm 24{ }^{14} \mathrm{C} \operatorname{yr}(n=3)$, which is quite different from the reported value of $109{ }^{14} \mathrm{C}$ yr for Shimoda (Yoneda et al. 2000). The discrepancy between this result and the previous study is now under consideration. Because many shell midden ruins exist especially in the Kanto region, the local reservoir correction values acquired in this study are very helpful in refining the archaeological chronology.

\section{Western Subtropical Pacific}

Niijima Island in the Izu Islands is $160 \mathrm{~km}$ south of Tokyo (region $\mathrm{f}$ in Figure 1). It is washed by the Kuroshio Warm Current, and the mean $\Delta \mathrm{R}$ value is a similar to those of the southwest islands of Japan, with a value of $21 \pm 21{ }^{14} \mathrm{C}$ yr $(n=3)$. In the case of the Ryukyu Islands, 3 shell samples for Amami Island (region $\mathrm{j}$ in Figure 1 and Table 1) and 11 shell samples for Okinawa Island (region $\mathrm{k}$ ) were analyzed. A mean $\Delta \mathrm{R}$ of $-25 \pm 20{ }^{14} \mathrm{C}$ yr $(n=3)$ for the Amami region and $42 \pm 11{ }^{14} \mathrm{C} \mathrm{yr}(n=$ 11) for the Okinawa region were calculated. The estimated values for the Okinawa region showed good agreement to the mean $\Delta \mathrm{R}$ of $29 \pm 18{ }^{14} \mathrm{C}$ yr for Amami Island and the Okinawa region (Yoneda et al. 2007). On the other hand, the value for the Amami region seems to be smaller. The mean values of $\Delta \mathrm{R}$ were estimated for the Amami region as $5 \pm 15{ }^{14} \mathrm{C} \mathrm{yr}(n=6 ; 3$ from this work and 3 from Yoneda et al. 2007), and for the Okinawa region as $38 \pm 10{ }^{14} \mathrm{C} \mathrm{yr}(n=13 ; 11$ from this work and 2 from Yoneda et al. 2007). The mean value for the Okinawa region is larger than that for the Amami region, but the value calculated only for Bivalvia shells was $4 \pm 13{ }^{14} \mathrm{C}$ yr $(n=7)$ for the Okinawa region. The discrepancy between the $\Delta \mathrm{R}$ values for the Amami region and those for the Okinawa region is now under consideration.

\section{CONCLUSION}

Local correction values for a total of 40 shell samples were calculated for 11 regions (Figure 4). In the region north of the main islands, the values were $12 \pm 24{ }^{14} \mathrm{C}$ yr for point "a" and $18 \pm 35{ }^{14} \mathrm{C} \mathrm{yr}$ for point "b" in Figure 2, and it is estimated that the area containing "a" and "b" is affected by water masses of the Tsugaru Warm Current. Similarly, in the Ryukyu Islands and the Izu Islands where the Kuroshio Warm Current is an influence, the mean values of $\Delta \mathrm{R}$ were comparatively small: $21 \pm 21$ ${ }^{14} \mathrm{C} \operatorname{yr}(n=3)$ for the Izu Islands; $5 \pm 15{ }^{14} \mathrm{C}$ yr $(n=6)$ for the Amami region; and $38 \pm 10{ }^{14} \mathrm{C}$ yr $(n$ =13) for the Okinawa region. On the other hand, in the central part of the main islands, the values were rather high. The mean $\Delta \mathrm{R}$ values for Chiba Prefecture (region e in Figure 3) were estimated at $81 \pm 15{ }^{14} \mathrm{C}$ yr $(n=7)$, and those for Tokyo Bay (region g in Figure 3) were $61 \pm 22{ }^{14} \mathrm{C}$ yr $(n=3)$, and those for the Miura Peninsula and Sagami Bay (region h in Figure 3) were $89 \pm 22{ }^{14} \mathrm{C}$ yr $(n=$ 54). Since many shellmounds are distributed throughout the Kanto District, this value is very useful for correctly determining archaeological ages. 


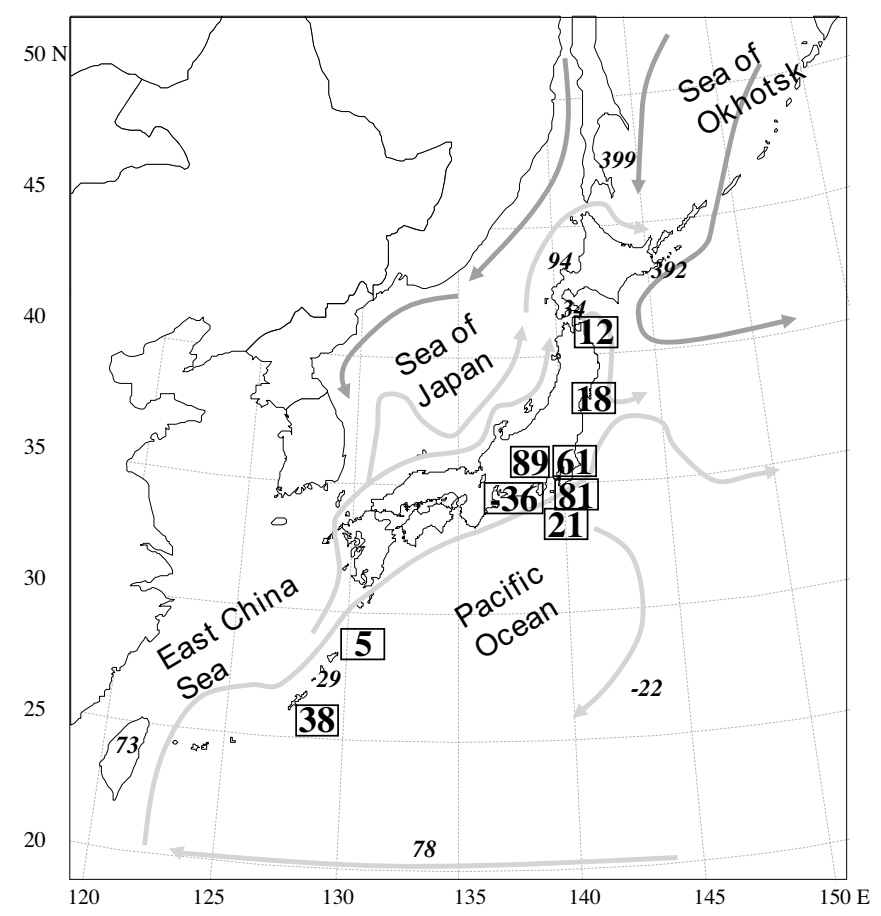

Figure 4 The mean values of $\Delta \mathrm{R}$ in the western Pacific. Numbers within squares are obtained by this work; italicized numbers are previous data.

The reservoir ages in the Pacific coast of the Japanese Archipelago were clarified in detail for the first time.

\section{REFERENCES}

Broecker WS. 2002. The Glacial World According to Wally. Palisades: Eldigio Press. 76 p.

Chinzei K, Fujioka K, Kitazato H, Koizumi I, Oba T, Oda M, Okada H, Sakai T, Tanimura Y. 1987. Postglacial environmental change of the Pacific Ocean off the coast of central Japan. Marine Micropaleontology 11(4):273-91.

Crane HR, Griffin JB. 1960. University of Michigan radiocarbon dates V. Radiocarbon 2:31-48.

Hideshima S, Matsumoto E, Abe O, Kitagawa H. 2001. Northwest Pacific marine reservoir correction estimated from annually banded coral from Ishigaki Island, southern Japan. Radiocarbon 43(2A):473-6.

Hughen KA, Baillie MGL, Bard E, Beck JW, Bertrand CJH, Blackwell PG, Buck CE, Burr GS, Cutler KB, Damon PE, Edwards RL, Fairbanks RG, Friedrich M, Guilderson TP, Kromer B, McCormac G, Manning S, Bronk Ramsey C, Reimer PJ, Reimer RW, Remmele S, Southon JR, Stuiver M, Talamo S, Taylor FW, van der Plicht J, Weyenmeyer CE. 2004. Marine04 marine radiocarbon age calibration, 0-26 cal kyr BP. Radiocarbon 46(3):1059-86.
Kigoshi K. 1967. Gakushuin natural radiocarbon measurement VI. Radiocarbon 9:43-62.

Kuzmin YV, Burr GS, Jull AJT. 2001. Radiocarbon reservoir correction ages in the Peter the Great Gulf, Sea of Japan, and eastern coast of the Kunashir, southern Kuriles (northwestern Pacific). Radiocarbon 43(2A): 477-81.

Nakamura T, Nishida I, Takada H, Okuno M, Minami M, Oda H. 2007. Marine reservoir effect deduced from ${ }^{14} \mathrm{C}$ dates on marine shells and terrestrial remains at archaeological sites in Japan. Nuclear Instruments and Methods in Physics Research B 259(1):453-9.

Niimura Y, Irino T, Oba T. 2006. Paleoenvironmental change off Kashima of central Japan during the last 144,000 years based on planktonic foraminiferal assemblage. Fossils 79:4-17. In Japanese with English summary.

Reimer PJ, Baillie MGL, Bard E, Bayliss A, Beck JW, Bertrand CJH, Blackwell PG, Buck CE, Burr GS, Cutler KB, Damon PE, Edwards RL, Fairbanks RG, Friedrich M, Guilderson TP, Hogg AG, Hughen KA, Kromer B, McCormac G, Manning S, Bronk Ramsey 
C, Reimer RW, Remmele S, Southon JR, Stuiver M, Talamo S, Taylor FW, van der Plicht J, Weyhenmeyer CE. 2004. IntCal04 terrestrial radiocarbon age calibration, 0-26 cal kyr BP. Radiocarbon 46(3):102958.

River Bureau, Ministry of Land and Infrastructure, Transport and Tourism. 2004. Flow rate chronological table. Japanese River Association. Tokyo.

Sanseido Publishing Company. 2002. Encyclopedia of Japanese Archaeology. Tokyo: Sanseido Publishing Co. In Japanese.

Shishikura M, Echigo T, Kaneda. 2007. Marine reservoir correction for the Pacific coast of central Japan using ${ }^{14} \mathrm{C}$ ages of marine mollusks uplifted during historical earthquakes. Quaternary Research 67(2):286-91.

Stuiver M, Braziunas TF. 1993. Modeling atmospheric ${ }^{14} \mathrm{C}$ influences and ${ }^{14} \mathrm{C}$ ages of marine samples to 10,000 BC. Radiocarbon 35(1):137-58.

Yoneda M, Kitagawa H, van der Plicht J, Uchida M, Tanaka A, Uehiro T, Shibata Y, Morita M, Ohno T. 2000. Pre-bomb marine reservoir ages in the western North Pacific: preliminary result on Kyoto University collection. Nuclear Instruments and Methods in Physics Research B 172(1-4):377-81.
Yoneda M, Hirota M, Uchida M, Uzawa K, Tanaka A, Shibata Y, Morita M. 2001. Marine radiocarbon reservoir effect in the western North Pacific observed in archaeological fauna. Radiocarbon 43(2A):465-71.

Yoneda M, Uno H, Shibata Y, Suzuki R, Kumamoto Y, Yoshida K, Sasaki T, Suzuki A, Kawahata H. 2007. Radiocarbon marine reservoir ages in the western $\mathrm{Pa}$ cific estimated by pre-bomb molluscan shells. $\mathrm{Nu}$ clear Instruments and Methods in Physics Research B 259(1):432-7.

Yoshida K, Miyazaki M. 2001. Methods of radiocarbon dating at Tell Kosak Shamali. In: Tell Kosak Shamali. UMUT Monograph 1. Tokyo: University of Tokyo, University Museum. p 158-63.

Yoshida K, Ohmichi J, Kinose M, Iijima H, Oono A, Abe N, Miyazaki Y, Matsuzaki H. 2004. The application of ${ }^{14} \mathrm{C}$ dating to potsherds of the Jomon period. Nuclear Instruments and Methods in Physics Research B 223224:716-22.

Yoshida K, Ryozuka M, Kinose M, Miyazaki Y, Hara T, IIjma H. 2008. ${ }^{14} \mathrm{C}$ age of the shell midden of Jomon period in Ichikawa City. In: Data Book of the Shell Midden of Jomon Period. Ichikawa City. In Japanese. p 151-62. 